\title{
Consistent parenting in the times of electronic media as a predictor of adolescent health and good relations in the family
}

\author{
Konsekwentne rodzicielstwo w czasach mediów elektronicznych jako predyktor zdrowia \\ nastolatków i dobrych relacji w rodzinie
}

\author{
1 Department of Child and Adolescents Health, Institute of Mother and Child, Warsaw, Poland \\ ${ }^{2}$ Institute of Psychology, The Maria Grzegorzewska University, Warsaw, Poland \\ Correspondence: Dorota Zawadzka PhD, Assistant Professor at the Maria Grzegorzewska University (APS), Institute of Psychology, Department of Clinical Psychology of Children and Adolescents, \\ Szczęśliwicka 40,02-353 Warsaw, Poland, e-mail: dzawadzka@aps.edu.pl; Senior Assistant - Specialist at Institute of Mother and Child, Department of Child and Adolescents Health, Kasprzaka 17a, \\ 01-211 Warsaw, Poland, e-mail: dorzawadzka@imid.med.pl
}

\author{
'Zakład Zdrowia Dzieci i Młodzieży, Instytut Matki i Dziecka, Warzzawa, Polska \\ ${ }^{2}$ Instytut Psychologii, Akademia Pedagogiki Specjalnej im. Marii Grzegorzewskiej, Warszawa, Polska \\ Adres do korespondencji: Dorota Zawadzka, Adiunkt w Zakładzie Psychologii Klinizznej Dzieci i Młodzieży, Akademia Pedagogiki Specjalnej im. Marii Grzegorzewskiej, ul. Szcześliwicka 40, 02-353 Warszawa, \\ e-mail: dzawadzka@aps.edu.pl; Starszy Asystent - Specjalista w Zakładzie Zdrowia Dzieci i Młodzieży, Instytut Matki i Dziecka, ul. Kasprzaka 17a, 01-211 Warszawa, e-mail: dorzawadzka@imid.med.pl
}

\begin{abstract}
Aim: The aim of the paper was to investigate the relationships between introducing family rules for phone and computer use, compliance with these rules and the frequency and methods of electronic media use, health, life satisfaction and relationships of adolescents with their parents. Materials and methods: An anonymous survey was conducted in Poland among 844 students aged $10-18$ years ( $55.3 \%$ boys; $28.0 \%$ were primary school students, $42.3 \%$ were lower secondary school students, $29.7 \%$ were upper secondary school students; $45.3 \%$ were residents of big cities, with populations of over $100,000,23.1 \%$ were residents of small towns and $31.6 \%$ were rural residents). The questionnaire included questions and scales relating to electronic media use (different activities and rules for the use of electronic media), health (self-rated health, subjective health complaints, life satisfaction) and family relations (clear communication, social support and shared activities). Results: A total of $97.7 \%$ of adolescents have access to a computer at home (no difference in terms of gender, age and place of residence), while $80.7 \%$ of adolescents have a computer or a laptop for their own exclusive use (the percentage grows with the level of education, from $77.4 \%$ to $87.6 \%$ ); $87.4 \%$ of respondents own a device with Internet access, $97.1 \%$ have a mobile phone (girls slightly more often than boys: $98.6 \%$ vs. $95.8 \%$ ). Adolescents who fail to comply with family rules on the use of electronic media dedicate the most amount of time to use these media for entertainment and face the most serious health and social consequences. Introduction of time restrictions by parents reduces the time devoted by adolescents to electronic media, but only the time spent on entertainment. Conclusions: Introduction and consistent compliance with the rules for using electronic media are important for good family relationships and are associated with clear communication, support, and spending time with parents.
\end{abstract}

Keywords: consistent parenting, electronic media, adolescent health, good family relationships

Streszczenie Cel: Celem pracy było zbadanie związków między wprowadzeniem zasad korzystania z telefonu i komputera w rodzinie a ich przestrzeganiem oraz częstotliwości i metod korzystania z mediów elektronicznych, zdrowia, zadowolenia z życia i relacji nastolatków z rodzicami. Materiał i metody: Anonimowe badanie przeprowadzono w Polsce na próbie 844 uczniów w wieku 10-18 lat (chłopcy - 55,3\%; uczniowie szkół podstawowych - 28,0\%, uczniowie gimnazjów - 42,3\%, uczniowie szkół średnich 29,7\%; mieszkańcy dużych miast, powyżej 100000 ludności - 45,3\%, mieszkańcy małych miast - 23,1\%, mieszkańcy wsi - 31,6\%). Kwestionariusz obejmował pytania i skale dotyczące korzystania z mediów elektronicznych (różne działania i zasady korzystania z mediów elektronicznych), zdrowia (samoocena zdrowia, subiektywne dolegliwości zdrowotne, zadowolenie z życia) i relacji rodzinnych (jasna komunikacja, wsparcie społeczne i wspólne działania). Wyniki: Spośród nastolatków 97,7\% ma dostęp do komputera w domu (bez różnicy pod względem płci, wieku i miejsca zamieszkania), a 80,7\% nastolatków ma komputer lub laptop do wyłącznego użytku (odsetek rośnie z poziomem edukacji, z 77,4\% do 87,6\%); 87,4\% posiada urządzenie z dostępem do Internetu, a 97,1\% telefon komórkowy (dziewczynki nieco częściej niż chłopcy: 98,6\% vs 95,8\%). Młodzież z grupy, w której rodzinne zasady korzystania z mediów elektronicznych nie są przestrzegane, poświęciła najwięcej czasu na korzystanie z tych mediów w celach rozrywkowych, a także poniosła najpoważniejsze konsekwencje zdrowotne i społeczne. Wprowadzenie ograniczeń czasowych przez 
rodziców skraca czas spędzany przez młodzież na używaniu mediów elektronicznych jedynie w celach rozrywkowych. Wnioski: Wprowadzenie i konsekwentne przestrzeganie zasad dotyczących korzystania z mediów elektronicznych jest elementem dobrych relacji w rodzinie i wiąże się z jasną komunikacją, wsparciem i spędzaniem czasu z rodzicami.

Słowa kluczowe: konsekwentne rodzicielstwo, media elektroniczne, zdrowie nastolatków, dobre relacje w rodzinie

\section{INTRODUCTION}

$\mathrm{E}$ lectronic media have become an integral part of $21^{\text {st }}$ century adolescent life. More than $90 \%$ of adolescents use computers and the Internet, and have their own accounts on social networking websites (Eurostat, 2015). Also, the number of adolescents who own mobile phones has definitely been on the rise, as has the frequency of their use of these devices (Lenhart, 2012). Only a third of adolescents in Europe comply with experts' recommendations regarding the time spent in front of a TV or computer screen, which is a maximum of two hours per day (Boniel-Nissim et al., 2015). According to US studies, an average adolescent devotes 7.5 hours per day to electronic media (Rideout et al., 2010).

A large body of research suggests that adolescent activity on Internet forums increases the risk of cyberbullying and behavioural addictions (Wolak et al., 2007). There is a negative association between computer use and family relationships (Rideout et al., 2010). Correlations have also been found with family conflicts, poor communication and bonding, higher frequency of making friends online and pathological Internet use (Lei and Wu, 2007; Wolak et al., 2003). At the same time, watching TV and playing computer games have been found to have a positive impact on visual and spatial abilities as well as problem solving skills and school achievements (Schmidt and Vandewater, 2008). Electronic media may also enhance communication among peers, though at the expense of contacts with parents, whose knowledge of their children's activities is becoming increasingly limited, especially in terms of their online activity. There is a positive correlation between risks and opportunities connected with electronic media use, implying that efforts to enhance these opportunities may involve an increased risk, and that efforts to minimise the risk may inadvertently decrease children's opportunities to benefit from Internet use (Livingstone et al., 2015).

\section{Adolescent health}

Adolescence is regarded as one of the healthiest periods in human life. According to the latest international studies, Health Behaviour in School-aged Children (HBSC), 91\% of 11 -year-olds, $86 \%$ of 13 -year-olds and $83 \%$ of 15 -yearolds rate their health as good or very good (Ottova-Jordan et al., 2016). Cavallo et al. (2015) tracked the trends in selfassessment of health among teenagers from 32 countries in while at the beginning of this decade in most countries subjective health indicators were improving, in 2006-2010 this positive trend had fallen or even reversed. This can be attributed to the general economic crisis and increasing difficulties in accomplishing the developmental tasks of adolescence and the transition to adulthood (Mazur, 2015). In 2014, subjective health indicators began to slightly improve (Ottova-Jordan et al., 2016).

Many authors point to the fact that a significant number of adolescents experience psychosomatic disorders (such as headaches, stomach aches, depressed mood and irritation) related primarily to stress and difficulties in coping with developmental tasks (Brolin Låftman and Modin, 2012; Tabak and Mazur, 2016). The prevalence of multiple health complaints increases with age and is higher among girls than boys (Ottova-Jordan et al., 2016). In Poland, $38.2 \%$ of adolescents experience two or more subjective health complaints at least once a week, and the rates increase with growing poverty and the disintegration of the family structure (Mazur, 2015). These complaints should not be ignored as their frequent occurrence might be a predictor of worse health in adulthood (Hofstra et al., 2001).

The health of adolescents is strongly affected by behavioural and social factors. Crucial behaviours protecting adolescents' health include proper diet and physical activity. The most common harmful behaviours include the use of psychoactive substances, sexual activity, violence and sedentary behaviours, with an emphasis on the use of electronic media (Inchley et al., 2016). Analyses of the health consequences of media use indicate that the time spent in front of a computer or TV is associated with a greater risk of overweight and obesity, socio-emotional problems, poorer general and oral health status (Russ et al., 2009), increased violence, anxiety, depression, irregular sleep, attention deficits, earlier sexual activity (Kappos, 2007; Strasburger et al., 2010), tiredness, subjective insomnia (Cain and Gradisar, 2010), psychological distress, depression and poorer health-related quality of life (Mathers et al., 2009).

The strongest social determinants of adolescent health are distal factors (national wealth, income inequality, access to education), and proximal factors (safe and supportive families and schools, positive and supportive peers) (Viner et al., 2012). They enable young people to develop to their full potential and attain the best health in the transition to adulthood. Family is a source of meaningful relationships, support, values, role models and 
health practices (Christensen, 2004; Wille et al., 2008). An analysis of adolescent health simultaneously in behavioural and social contexts (e.g. parenting and using electronic media) is necessary for planning effective health promotion programmes.

\section{Parenting styles}

According to Baumrind's $(1971,1991)$ taxonomy of parenting styles (authoritarian, authoritative, permissive and neglectful), parenting types differ on the bases of commitment and balance of demandingness and responsiveness. Authoritative parents who are highly demanding and highly responsive are remarkably successful in protecting their adolescents from psychological and behavioural dysfunction and in generating competence (Baumrind, 1991; Steinberg et al., 2006, 1994). In addition to the differences in responsiveness and demandingness, the parenting styles also differ in the extent to which they are characterised by psychological control (Darling, 1999). Both authoritarian and authoritative parents place high demands on their children and expect them to behave appropriately and to obey parental rules. Authoritarian parents, however, also expect their children to accept their judgments, values and goals without questioning. In contrast, authoritative parents are more open to give and take with their children and make greater use of explanations. The authoritative parenting style fits most closely within the consistent parenting approach.

Baumrind (2012) argues that children's well-being is impacted by how their parents assert power to control their behaviour and whether they do so routinely. The kind of power that characterises authoritarian parents is coercive (arbitrary, domineering, concerned with marking status distinctions), whereas the kind of power that characterises authoritative parents is confrontive (reasoned, negotiable, outcome-oriented, concerned with regulating behaviours). The effects of power assertion are detrimental only when coercive, so the common presumption that power-assertive disciplinary practices per se are harmful is unjustified (Baumrind, 2012).

A review of studies published between 1996-2007 that address specific relationships between parenting styles and adolescent risk behaviours supports the substantial influence of parenting style on adolescent development (Newman et al., 2008). Adolescents raised in authoritative households consistently demonstrate higher protective and fewer risk behaviours than adolescents from non-authoritative families. Parenting styles and behaviours related to warmth, communication and disciplinary practices predict important mediators, including academic achievements and psychosocial adjustment. According to Strasburger et al. (2014), what parents do around children's use of electronic media is likely to be influenced by their general approach to parenting and their beliefs about how best to raise children.

\section{Families and electronic media}

Recent social and economic transformation has influenced the image of a contemporary family. Rapid economic development and improving economic situation of many households have resulted in a greater availability of a broad spectrum of consumer services and goods, even in times of economic crisis (Eurofound, 2014). Owning at least one TV set with at least a dozen TV channels, along with a computer connected to the Internet, has become a standard for a European family (Eurostat, 2015). So has the use of mobile phones by all family members in most households. Watching cartoons, playing computer games and video games have become children's favourite activities (Rideout and Hamel, 2006).

An important factor influencing the time spent by children in front of the TV/DVD or computer is the attitude of their parents towards TV, gaming or the Internet. The majority of parents are not apprehensive about TV they consider watching TV to be a form of education (De Decker et al., 2012). They cite education as one of the benefits of watching TV programmes, and see no need to introduce rules for the use of electronic media. Parental TV habits influence their positive attitude towards their children's use of TV without any rules being set. A qualitative analysis conducted by Shin (2015) showed that parents of children aged 7-12 years also presumed that the influence of the Internet on their children was more positive than negative and that they felt confident about their ability to manage their children's Internet use. This high parental confidence in their own management, however, seemed to lead parents to be less engaged in purposeful and communication-based parental mediation (Alqahtani et al., 2017).

Studies on the time spent by children watching TV and playing games show that the qualities of the physical environment, i.e., a smaller number of TV sets in the household and their absence in children's bedrooms, were helpful in reducing the time spent by them watching TV and playing games (Veldhuis et al., 2014). The authors emphasised that reducing screen time poses a great challenge for parents. Social changes promote the use of TV and games. Broadcasters offer a wide range of TV channels dedicated to children, game manufacturers increase the number of games available to children, and there also has been a great rise in the use of electronic media in children's education. For these reasons, parents may experience difficulties in limiting their children's screen time.

\section{Reducing adolescent screen time}

Studies on the factors protecting adolescents from excessive TV watching and video game playing showed that changes in four family-related factors (modelling parental attitudes, surveillance, rigour and the accessibility of 
TV sets and video game consoles) were indeed correlated with reduced time spent by children watching TV and playing video games (Van Lippevelde at al., 2014). Brooks et al. (2016), using data from the HBSC study, showed that adolescents who reported parental input into the decision-making about the use of free time outside school were less likely to engage in higher video game usage than those who had complete autonomy. However, this difference was smaller for those who had to adhere to their parents' decisions (parents with authoritarian control over the decision-making processes in the family).

Correlational studies of adolescents from five European countries have identified relationships between the style of communicating the rules on the use of electronic media (TV/DVD, computer games and consoles) and the actual time spent by children in front of TV or playing video games. An autonomous and supportive style of communicating the rules on the use of electronic equipment was correlated with a shorter screen time among children; an opposite situation occurred when parents used a controlling style (Bjelland et al., 2015).

Research on adolescents from the UK has confirmed that children do indeed exceed the World Health Organization recommendations for watching TV when both parents fail to sufficiently limit activities that lead to a sedentary lifestyle (Jago et al., 2001). As a matter of fact, children of mothers with a liberal parenting style spend more hours in front of a screen. The authors emphasise that knowledge of the framework needed for correct child development might help in adopting an authoritative parenting style. This would foster responsibility among children, who would learn the arguments justifying the decision on limiting screen time. Researchers point to the fact that the effectiveness of various modes of communicating restrictive rules requires further research. Parents will also need support in coping with child resistance against restrictive practices.

According to US studies, parental introduction of time restrictions reduces the time devoted by adolescents to electronic media by nearly a half (Rideout et al., 2010). Lee's (2013) confirmed that parental restrictive mediation is significantly associated with reduced online risks and reduced time spent online, and the effects of restrictive mediation on online time and online risks are greater for a child with low self-control. Shin and Kang (2016) confirmed the role of parental mediation (both restrictive and instructive) in reducing time spent online, but revealed that instructive mediation is more effective than restrictive mediation in reducing privacy risks.

An analysis of parental mediation in the EU Kids Online survey of 9-16-year-olds in 25 countries showed that restrictive mediation (setting rules and restrictions on how children can use the Internet) reduces online risks, but it also reduces their online opportunities and skills (Duerager and Livingstone, 2012; Livingstone et become resilient, and they are also more likely to adopt passive responses to online risks. Active parental mediation (actively talking to or sitting with children or sharing online activities) is associated with lower online risk of harm as well as children enjoying more online opportunities and gaining more digital skills (Livingstone et al., 2015).

\section{Present study}

Previous research demonstrated that parental communication of the rules on the use of electronic media plays an important role in reducing time spent by adolescents in front of electronic devices (Livingstone et al., 2015; Rideout et al., 2010, Van Lippevelde et al., 2014). Our study is the first attempt to identify the key element responsible for the effectiveness of these rules - introduction of or consistent compliance with with the rules.

This article is an attempt to answer the questions on whether it is introducing or complying with family rules for phone and computer use that is a factor protecting adolescents against the negative health and social consequences of electronic media use. The aim of the paper was to investigate the correlations between introducing family rules for phone and computer use, complying with these rules, and the frequency and methods of electronic media use, health, life satisfaction and relationships of adolescents with their parents.

\section{MATERIALS AND METHODS}

\section{Sample and procedure}

An anonymous survey was conducted in Poland in 15 schools located in cities with various population sizes, 5 schools at each stage of education (primary, lower secondary, upper secondary). The survey included 844 students aged $10-18$ years $(M=14.2$; standard deviation, $S D=2.0)$, including $55.3 \%$ of boys; primary school students accounted for $28.0 \%(M=11.8$; $S D=0.9)$, lower secondary school students accounted for $42.3 \%$ $(M=14.1 ; S D=0.9)$, upper secondary school students for $29.7 \%(M=16.6$; $S D=0.6) ; 45.3 \%$ were residents of big cities (with populations of over 100,000), 23.1\% were residents of small towns and $31.6 \%$ were rural residents. The surveys were approved by the local Bioethics Committee at the Institute of Mother and Child as well as informed consent of the school principals and participants' parents was obtained.

\section{Questionnaire}

The questionnaire included questions and scales relating to the following:

- Sociodemographic variables: gender, age, level of education, place of residence, perceived family wealth (How well 
mobile phone

computer

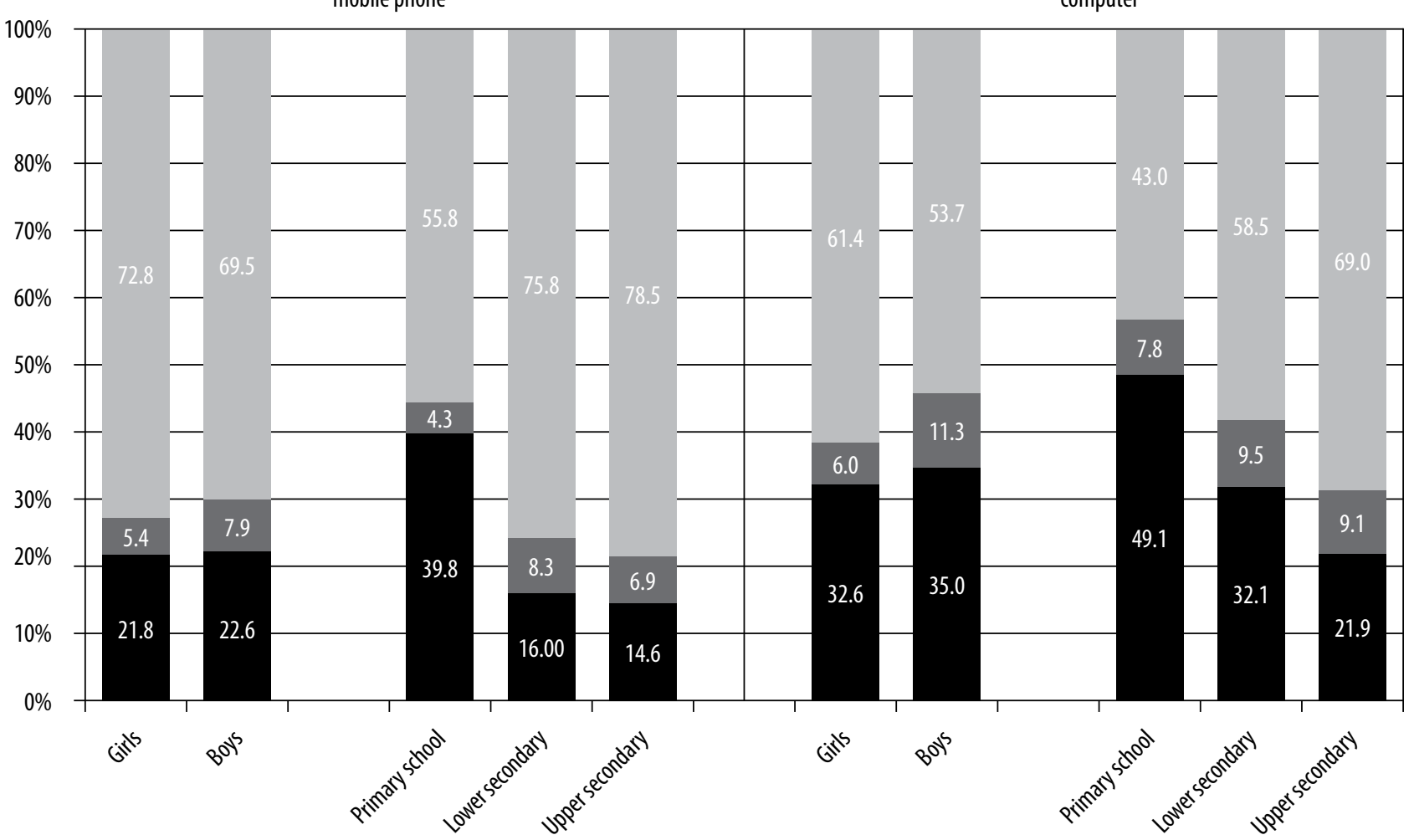

Fig. 1. Introduction of and compliance with the rules on electronic media use by gender and level of education

off do you think your family is? with answer categories from very well off to not at all well off) (Currie et al., 2014).

- Electronic media use: ownership of devices and access to the Internet, frequency of using electronic media for different activities (e.g. watching films, social contacts, listening to music, playing games) with answers ranging from never to everyday; the rules for electronic media use (At home, do you have any rules regarding the time, place and circumstances of using a mobile phone or a computer?), with answers categories: yes, and they are followed; yes, but they are not followed; not.

- Health: Self-rated health (from poor to excellent), subjective health complaints [HBSC Symptom Checklist (HBSC-SCL): headache, stomachache, backache, depressed mood, irritability or bad temper, feeling nervousness, sleeping problems, feeling dizzy], life satisfaction (Cantril ladder) - all health indicators derived from HBSC study questionnaire (Currie et al., 2014).

- Family relations: clear communication with parents [short communication scale from Family Dynamics Measure II (FDM II)], social support [family scale from Multidimensional Scale of Perceived Social Support (MSPSS)], shared activities in the family (Family life \& enjoyment of family activities scale) - all family indicators derived from HBSC study questionnaire (Currie et al., 2014).

All the scales were converted to a $0-100$ scale: the higher the score, the better the health and the family relations.

\section{Statistical analyses}

The statistical analysis of the data was conducted using SPSS v. 22 . The chi-squared test $\left(\chi^{2}\right)$ and Student's $t$-test were used for the evaluation of the differences associated with gender; the one-way analysis of variance (ANOVA) was used for comparisons of means of health and family relationship indicators between the three education level groups; and the Kruskal-Wallis tests was used for comparisons between family affluence and the introduction of rules on the use of electronic media. The use of the non-parametric KruskalWallis test was due to the unequal sample sizes. Multivariate logistic regression models (with gender, level of education and family wealth as controlled variables) were estimated for the assessment of the probability of adolescents' good health, life satisfaction and good family relationships depending on the consistent following of the rules for media use.

\section{RESULTS}

\section{Electronic media use}

A total of $97.7 \%$ of adolescents have access to a computer at home (no difference in terms of gender, age and place of residence), while $80.7 \%$ of adolescents have a computer or a laptop for their own exclusive use [the percentage grows with the level of education, from $77.4 \%$ to $87.6 \%$; 


\begin{tabular}{|c|c|c|c|c|c|c|c|c|c|c|c|c|}
\hline & \multirow[b]{2}{*}{$\begin{array}{c}\text { Total } \\
(N=844)\end{array}$} & \multicolumn{2}{|c|}{ Gender } & \multirow[b]{2}{*}{$p$} & \multicolumn{3}{|c|}{ Level of education } & \multirow[b]{2}{*}{$p$} & \multicolumn{3}{|c|}{ Perceived family wealth } & \multirow[b]{2}{*}{$p$} \\
\hline & & $\begin{array}{c}\text { Boys } \\
(n=466)\end{array}$ & $\begin{array}{c}\text { Girls } \\
(n=376)\end{array}$ & & $\begin{array}{c}\text { Primary } \\
\text { school } \\
(n=236) \\
\end{array}$ & $\begin{array}{c}\text { Lower } \\
\text { secondary } \\
(n=357)\end{array}$ & \begin{tabular}{|c|} 
Upper \\
secondary \\
$(n=251)$ \\
\end{tabular} & & $\begin{array}{l}\text { Well off } \\
(n=278)\end{array}$ & $\begin{array}{c}\text { Average } \\
(n=519)\end{array}$ & $\begin{array}{c}\text { Not well } \\
\text { off } \\
(n=28)\end{array}$ & \\
\hline \multicolumn{13}{|c|}{ Everyday electronic media activities [\%]* } \\
\hline Keeping social contacts & 60.3 & 59.4 & 61.4 & NS & 42.0 & 63.9 & 72.0 & 0.000 & 61.9 & 59.4 & 63.0 & NS \\
\hline \begin{tabular}{|l}
$\begin{array}{l}\text { Establishing social } \\
\text { contacts }\end{array}$ \\
\end{tabular} & 31.3 & 40.4 & 19.9 & 0.000 & 28.6 & 29.5 & 36.0 & NS & 37.5 & 27.7 & 25.9 & 0.014 \\
\hline Listening music & 65.4 & 65.4 & 65.5 & NS & 55.2 & 66.3 & 73.6 & 0.000 & 66.9 & 64.3 & 71.4 & NS \\
\hline Online gaming & 26.4 & 40.7 & 8.8 & 0.000 & 22.4 & 25.4 & 31.2 & 0.080 & 31.3 & 23.7 & 18.5 & 0.047 \\
\hline One-player gaming & 20.9 & 28.2 & 11.8 & 0.000 & 25.0 & 17.2 & 22.0 & 0.066 & 24.9 & 18.0 & 14.8 & 0.055 \\
\hline Watching films & 24.1 & 31.0 & 15.5 & 0.000 & 24.2 & 22.5 & 26.5 & NS & 28.4 & 21.2 & 35.7 & 0.026 \\
\hline Searching news & 15.8 & 18.5 & 12.4 & 0.016 & 16.0 & 12.8 & 18.5 & NS & 18.1 & 14.2 & 14.8 & NS \\
\hline $\begin{array}{l}\text { Searching information } \\
\text { about hobbies }\end{array}$ & 27.8 & 32.4 & 22.0 & 0.001 & 21.4 & 28.2 & 33.2 & 0.016 & 28.4 & 27.5 & 22.2 & NS \\
\hline \multicolumn{13}{|c|}{ Health $[M(S D)]^{* *}$} \\
\hline Self-rated health & $\begin{array}{l}79.73 \\
(15.9) \\
\end{array}$ & $\begin{array}{l}81.14 \\
(16.6) \\
\end{array}$ & $\begin{array}{r}78.00 \\
(14.8) \\
\end{array}$ & 0.004 & $\begin{array}{l}82.66 \\
(15.3) \\
\end{array}$ & $\begin{array}{l}77.53 \\
(15.3) \\
\end{array}$ & $\begin{array}{l}80.08 \\
(16.7) \\
\end{array}$ & 0.001 & $\begin{array}{l}81.83 \\
(14.9) \\
\end{array}$ & $\begin{array}{l}78.76 \\
(15.9) \\
\end{array}$ & $\begin{array}{l}74.07 \\
(18.9) \\
\end{array}$ & 0.010 \\
\hline $\begin{array}{l}\text { Lack of subjective } \\
\text { health complaints }\end{array}$ & $\begin{array}{l}77.17 \\
(19.9)\end{array}$ & $\begin{array}{l}80.47 \\
(17.1)\end{array}$ & $\begin{array}{l}73.03 \\
(22.2) \\
\end{array}$ & 0.000 & $\begin{array}{l}84.74 \\
(15.4) \\
\end{array}$ & $\begin{array}{l}73.55 \\
(22.2) \\
\end{array}$ & $\begin{array}{l}75.56 \\
(18.1) \\
\end{array}$ & 0.000 & $\begin{array}{l}79.51 \\
(19.1) \\
\end{array}$ & $\begin{array}{l}76.99 \\
(19.4) \\
\end{array}$ & $\begin{array}{l}57.33 \\
(24.6) \\
\end{array}$ & 0.000 \\
\hline Life satisfaction & $\begin{array}{l}75.49 \\
(19.8) \\
\end{array}$ & $\begin{array}{l}75.96 \\
(19.6) \\
\end{array}$ & $\begin{array}{r}74.86 \\
(19.9) \\
\end{array}$ & NS & $\begin{array}{l}83.36 \\
(17.2) \\
\end{array}$ & $\begin{array}{l}72.12 \\
(20.2) \\
\end{array}$ & $\begin{array}{l}72.79 \\
(19.4) \\
\end{array}$ & 0.000 & $\begin{array}{l}80.32 \\
(18.4) \\
\end{array}$ & $\begin{array}{l}74.14 \\
(18.6) \\
\end{array}$ & $\begin{array}{l}49.26 \\
(29.3) \\
\end{array}$ & 0.000 \\
\hline \multicolumn{13}{|c|}{ Family relationships $[M(S D)]^{* *}$} \\
\hline Clear communication & $\begin{array}{l}63.62 \\
(15.7) \\
\end{array}$ & $\begin{array}{l}64.24 \\
(14.9) \\
\end{array}$ & $\begin{array}{l}62.81 \\
(16.6) \\
\end{array}$ & NS & $\begin{array}{l}67.57 \\
(13.9) \\
\end{array}$ & $\begin{array}{l}62.14 \\
(16.8) \\
\end{array}$ & $\begin{array}{l}62.11 \\
(15.1)\end{array}$ & 0.000 & $\begin{array}{c}66.5 \\
(14.1) \\
\end{array}$ & $\begin{array}{l}63.11 \\
(15.5) \\
\end{array}$ & $\begin{array}{l}43.70 \\
(19.9) \\
\end{array}$ & 0.000 \\
\hline Social support & $\begin{array}{l}79.40 \\
(20.5) \\
\end{array}$ & $\begin{array}{l}79.42 \\
(20.7) \\
\end{array}$ & $\begin{array}{l}79.30 \\
(20.4) \\
\end{array}$ & NS & $\begin{array}{l}85.26 \\
(18.5) \\
\end{array}$ & $\begin{array}{l}77.61 \\
(21.7) \\
\end{array}$ & $\begin{array}{l}76.52 \\
(19.6) \\
\end{array}$ & 0.000 & $\begin{array}{l}82.64 \\
(19.5) \\
\end{array}$ & $\begin{array}{l}78.97 \\
(19.9)\end{array}$ & $\begin{array}{l}55.63 \\
(24.6)\end{array}$ & 0.000 \\
\hline Common activities & $\begin{array}{l}43.10 \\
(15.9)\end{array}$ & $\begin{array}{l}43.29 \\
(15.5)\end{array}$ & $\begin{array}{l}42.91 \\
(16.4)\end{array}$ & NS & $\begin{array}{l}50.51 \\
(15.4)\end{array}$ & $\begin{array}{l}42.52 \\
(15.6)\end{array}$ & $\begin{array}{l}37.31 \\
(14.2)\end{array}$ & 0.000 & $\begin{array}{l}47.54 \\
(16.6)\end{array}$ & $\begin{array}{l}41.46 \\
(14.6)\end{array}$ & $\begin{array}{l}28.06 \\
(18.3)\end{array}$ & 0.000 \\
\hline
\end{tabular}

Tab. 1. Electronic media activities, health and family relationships by gender, level of education and family wealth

\begin{tabular}{|c|c|c|c|c|c|c|c|c|}
\hline & \multicolumn{3}{|c|}{ Mobile phone use rules } & \multirow[b]{2}{*}{$p$} & \multicolumn{3}{|c|}{ Computer use rules } & \multirow[b]{2}{*}{$p$} \\
\hline & $\begin{array}{l}\text { Yes, and they are } \\
\text { followed } \\
(n=184)\end{array}$ & $\begin{array}{l}\text { Yes, but they are } \\
\text { not followed } \\
(n=56)\end{array}$ & $\begin{array}{c}\text { Not } \\
(n=588)\end{array}$ & & $\begin{array}{l}\text { Yes, and they are } \\
\text { followed } \\
(n=278)\end{array}$ & $\begin{array}{c}\text { Yes, but they are } \\
\text { not followed } \\
(n=73)\end{array}$ & $\begin{array}{c}\text { Not } \\
(n=470)\end{array}$ & \\
\hline \multicolumn{9}{|c|}{ Everyday electronic media activities [\%] ${ }^{*}$} \\
\hline Keeping social contacts & 56.5 & 62.8 & 74.2 & 0.005 & 56.9 & 66.7 & 65.3 & 0.048 \\
\hline Establishing social contacts & 29.6 & 30.6 & 41.6 & 0.082 & 29.5 & 42.2 & 27.9 & 0.026 \\
\hline Listening music & 62.1 & 66.5 & 78.7 & 0.010 & 61.9 & 71.6 & 71.6 & 0.022 \\
\hline Online gaming & 22.9 & 30.3 & 28.1 & 0.087 & 22.7 & 32.7 & 28.9 & 0.051 \\
\hline One-player gaming & 19.8 & 20.4 & 23.6 & NS & 20.0 & 24.5 & 18.4 & NS \\
\hline Watching films & 24.3 & 24.2 & 20.2 & NS & 23.3 & 26.5 & 24.3 & NS \\
\hline Searching news & 15.9 & 13.6 & 19.1 & NS & 14.6 & 18.6 & 15.4 & NS \\
\hline Searching information about hobbies & 26.2 & 27.4 & 34.8 & NS & 27.0 & 33.3 & 25.8 & NS \\
\hline \multicolumn{9}{|c|}{ Health $[M(S D)]^{* *}$} \\
\hline Self-rated health & $83.42(15.4)$ & $76.79(18.4)$ & $78.67(15.5)$ & 0.000 & $81.11(16.1)$ & $75.69(15.7)$ & $79.06(15.7)$ & 0.000 \\
\hline Lack of subjective health complaints & $83.09(17.9)$ & $74.02(21.1)$ & $75.58(19.7)$ & 0.000 & $85.86(18.4)$ & $71.88(20.7)$ & $75.48(19.9)$ & 0.000 \\
\hline Life satisfaction & $83.68(17.1)$ & $72.68(21.5)$ & $72.92(19.4)$ & 0.000 & $79.78(17.6)$ & $70.41(20.3)$ & $73.21(20.1)$ & 0.000 \\
\hline \multicolumn{9}{|c|}{ Family relationships $[M(S D)]^{* *}$} \\
\hline Clear communication & $69.36(13.3)$ & $60.27(17.1)$ & $62.05(15.6)$ & 0.000 & $67.11(13.5)$ & $61.37(15.8)$ & $61.79(16.4)$ & 0.000 \\
\hline Social support & $85.81(18.6)$ & $72.79(23.7)$ & $\mid 78.06(20.1)$ & 0.000 & $84.08(18.1)$ & $75.05(22.6)$ & $77.65(20.7)$ & 0.000 \\
\hline Common activities & $51.07(16.0)$ & $42.28(17.3)$ & $40.65(14.8)$ & 0.000 & $48.10(15.6)$ & $43.02(16.7)$ & 40.05 (15.2) & 0.000 \\
\hline
\end{tabular}




\begin{tabular}{|c|c|c|c|c|c|c|c|}
\hline & \multirow{2}{*}{ Compared group } & \multicolumn{3}{|c|}{ Mobile phone } & \multicolumn{3}{|c|}{ Computer } \\
\hline & & $p$ & $\operatorname{Exp}(B)$ & $95 \% \mathrm{Cl}$ of $\operatorname{Exp}(\mathrm{B})$ & $p$ & $\operatorname{Exp}(B)$ & $95 \% \mathrm{Cl}$ of $\operatorname{Exp}(\mathrm{B})$ \\
\hline \multirow{2}{*}{$\begin{array}{l}\text { Perceived very good health } \\
(90-100)\end{array}$} & Rules introduced and followed & 0.022 & 1.832 & $1.093-3.069$ & NS & 0.868 & $0.540-1.313$ \\
\hline & Rules introduced, but not followed & NS & 1.494 & $0.716-3.117$ & 0.017 & 0.416 & $0.203-0.852$ \\
\hline \multirow{2}{*}{$\begin{array}{l}\text { Lack of subjective health complaints } \\
(90-100)\end{array}$} & Rules introduced and followed & 0.072 & 1.853 & $0.960-2.611$ & NS & 1.000 & $0.635-1.575$ \\
\hline & Rules introduced, but not followed & NS & 1.150 & $0.571-2.316$ & NS & 0.293 & $0.364-1.357$ \\
\hline \multirow{2}{*}{$\begin{array}{l}\text { Life satisfaction } \\
(90-100)\end{array}$} & Rules introduced and followed & 0.000 & 3.729 & $2.194-6.336$ & 0.076 & 0.643 & $0.395-1.047$ \\
\hline & Rules introduced, but not followed & NS & 1.227 & $0.580-2.569$ & 0.018 & 0.430 & $0.213-0.867$ \\
\hline \multirow{2}{*}{$\begin{array}{l}\text { Clear communication } \\
(75-100)\end{array}$} & Rules introduced and followed & 0.001 & 2.359 & $1.418-3.927$ & NS & 0.841 & $0.524-1.350$ \\
\hline & Rules introduced, but not followed & NS & 1.325 & $0.644-2.723$ & NS & 0.730 & $0.378-1.411$ \\
\hline \multirow{2}{*}{$\begin{array}{l}\text { Good social support } \\
(90-100)\end{array}$} & Rules introduced and followed & 0.007 & 1.963 & $1.199-3.212$ & NS & 1.181 & $0.756-1.845$ \\
\hline & Rules introduced, but not followed & NS & 0.864 & $0.423-1.765$ & NS & 0.874 & $0.467-1.637$ \\
\hline \multirow{2}{*}{$\begin{array}{l}\text { Common activities } \\
(50-100)\end{array}$} & Rules introduced and followed & 0.000 & 2.502 & $1.508-4.153$ & NS & 1.147 & $0.724-1.817$ \\
\hline & Rules introduced, but not followed & NS & 1.149 & $0.575-2.297$ & NS & 1.398 & $0.754-2.592$ \\
\hline
\end{tabular}

Tab. 3. Multivariate logistic regression models (gender, level of education and family wealth as controlled variables) estimated for the assessment of the probability of adolescents' good health, life satisfaction and good family relations depending on the consistent following of the introduced rules on media use

$\left.\left(\chi^{2}(2, n=838)=10.80 ; p=0.005\right)\right] ; 87.4 \%$ of respondents own a device with Internet access, $97.1 \%$ have a mobile phone [girls slightly more often than boys: $98.6 \%$ vs. $95.8 \%$ $\left(\chi^{2}(1, n=826)=5.74 ; p=0.017\right)$. A total of $29.0 \%$ of families have rules for mobile phone use, but $6.7 \%$ (23.3\% of families having rules) fail to comply with these rules (Fig. 1). There were significant age differences - the rules on the use of electronic media set by parents of primary school pupils were the most likely to be observed, whereas lower secondary school students were the least likely to follow the rules set by their parents $\left(\chi^{2}(4, n=828)=58.52 ; p<0.001\right)$. Similarly, $42.8 \%$ of families have rules on computer use, but $8.9 \%$ (20.8\% of families having rules) of these families fail to comply with them. Parents of boys $\left(\chi^{2}(2, n=819)=8.94 ; p=0.011\right)$ and younger students $\left(\chi^{2}(4, n=821)=40.85 ; p<0.001\right)$ are more likely to introduce rules for computer use.

The most common electronic media activities among adolescents include listening to music (65.4\%) and keeping social contacts (60.3\%) (Tab. 1). Gender differences were found for almost all analysed activities (boys are more engaged than girls); age (education level) differences were statistically significant only for keeping social contacts, listening to music and searching for information about hobbies (all of these increase with age). Perceived family wealth is a predictor only for the frequency of establishing social contacts, online gaming (most frequent in well-off families) and watching films (not well-off families). Introducing rules for electronic media use is associated only with three of the eight analysed daily activities: keeping and establishing social contacts, and listening to music (Tab. 2).

\section{Health}

Almost $80 \%$ of adolescents perceive their health as good or very good, more than $75 \%$ of young people are satisfied with their life, but $23 \%$ of them have at least one health complaint every week (Tab. 1). Boys reported fewer subjective health complaints and showed a more positive assessment of their health; primary school students had the best subjective health and life satisfaction; the same was the case with adolescents from well-off families. The lowest health indicators can be found in families who fail to follow their own rules, and the mean values of all used heath scales are very similar in groups with no rules and with rules introduced, but not followed (Tab. 2).

\section{Family relationships}

In all analysed family scales, the highest mean values were achieved by the youngest students (primary school) and by adolescents from well-off families (Tab. 1). There were no gender differences. The lowest indicators of family relationships were found in families who failed to comply with their own rules (except for shared activities, which occur least often in families who do not have any rules) (Tab. 2).

\section{Multivariable analyses}

Six estimated multivariate logistic regression models for the assessment of the probability of adolescents' perceived very good health, lack of subjective health complaints, high life satisfaction and good family relations (clear communication, high social support and many common activities) revealed that even after controlling for gender, level of education and perceived family wealth, introducing and following the rules for electronic media use remain significant predictors of adolescent health and social relations (Tab. 3). Statistically significant improvement in health, life satisfaction and family relations was observed in families introducing and following rules for mobile phone use (more than threefold). 
In families who introduce rules for computer use, but fail to follow them, deteriorated health and life satisfaction were observed in comparison with families without any rules for media use (more than double).

\section{DISCUSSION}

We conducted a study in a sample of 844 students aged 10-18 years to investigate the correlations between introducing and following family rules for electronic media use and the frequency of use of media, health, life satisfaction and family relationships. The study showed that young people in families who introduced rules for the use of electronic media and who consistently followed these rules spent the least time using digital media. Adolescents in the group with family rules for computer use that were not followed dedicated the most amount of time to using computers for entertainment (keeping and establishing social contacts, and listening to music). No significant correlations were found, for example, in terms of information searching. These adolescents also faced the most serious health consequences.

Our study confirmed earlier reports showing that the introduction of time restrictions by parents reduces the time devoted by adolescents to electronic media (Lee, 2013; Rideout et al., 2010; Shin and Kang, 2016). However, the analyses showed that it was the time spent on entertainment rather than the time intended for education or searching for information that was reduced. This indicates that concerns about limiting the development opportunities associated with the introduction of restrictions (Duerager and Livingstone, 2012; Livingstone et al., 2015) are not entirely correct as regards cognitive development.

Our study drew attention to the negative health consequences incurred by children in families with no restrictions on the use of electronic media or only theoretical limitations, which are not followed (the worst situation). Lower indicators of self-rated health and higher frequency of subjective health complaints may be associated with spending more hours using computers or other electronic devices (Mathers et al., 2009; Russ et al., 2009; Strasburger et al., 2010). This may result in a worse family climate, which may explain the lower life satisfaction of teenagers from such families.

We found the lowest indicators of clear family communication and support in the families who failed to comply with their own rules (except for shared activities, which occur the least often in the families who do not have any rules). The introduction and consistent compliance with the rules for the use of electronic media is an element of good relationships in the family and is related to clear communication, support, and spending time with parents. It can be an element of the authoritative parenting style, characterised by warmth, involvement, support of autonomy as well as clear rules and expectations (Baumrind, 1971, 2012, 1991;
This study shows a new direction in the analysis and the need to consider not only the existence of rules on the use of electronic media, but also their consistent compliance. This implies methodological conclusions regarding the construction of precise questions regarding the rules on the use of electronic media. The analysis of the data showed findings in line with current research directions, considering the methods of communicating rules on the use of modern media to adolescents (Bjelland et al., 2015; Livingstone et al., 2015). Restrictive implementation of rules generates much poorer results than supportive involvement. This may be associated with the natural resistance of young people to imposed rules, resulting in a lack of compliance. The EU Kids Online qualitative research conducted in nine countries showed that although children are generally positive about parental interventions in regards to their use of the Internet, they consider it to be problematic when parental advice is poorly articulated, not justified, and not expressed in a sensitive manner (Haddon, 2015).

In the case of modern technologies (computer, Internet, mobile), the changes which took place between 1994 and 2012 can be considered a revolution. The value of each rate of owning technology has systematically increased year after year during the entire analysed period in all voivodships in Poland. It was important to deliver new technologies to rural, poorer and less advanced regions in our country. The highest rate of owning a computer in rural household in 1994 was reported in Zachodniopomorskie (7.4\%), and, 18 years later, the rate was $71.5 \%$ in Wielkopolskie and $70.4 \%$ in Pomorskie. The number of houses with Internet access increased with the increasing computerisation level of rural households. In 2000, the highest rate of owning among rural households was noted in Opolskie - 3.3\%, in 2012 it was in Wielkopolskie $-66.2 \%$ and Pomorskie $66 \%$. Between 2000 and 2012, the number of rural households equipped with a mobile phone changed drastically, with the highest level of owning in 2000 in Lubuskie (17.4\%), and market saturation (about 100\%) in 2012, in e.g. Wielkopolskie (95.3\%). Systematic growth in the number of households equipped in various kinds of electronic media was not only due to the increasing wealth of occupants and decreasing exploitation costs, but also the increasing benefits of owning and using these devices on a daily basis (Śmiałowski et al., 2015). As a result of levelling the access to new technologies between rural and urban areas, it is possible to investigate global trends in Poland. In the first half of 2015, computers were present in $72 \%$ of households, including $71 \%$ with Internet access. There were differences in the level of market saturation in some types of families. Almost $95 \%$ of marriages with children own a computer and Internet access. There has also been a rapid growth in the use of tablets, which are present in every forth household, $3 \%$ of which do not own a computer. Between 2012 and 2014, a 15\% increase in the number of tablets may be noted. 
The popularity of laptops, which start to predominate over computers in households is noticeable (59\%). The readiness of Polish people to use technology with the Internet is well illustrated by the dynamic growth of smartphone usage - from $2.8 \%$ of population in 2011 to $44.8 \%$ in 2015 (Czapiński and Panek, 2015). The fastest growth of the group of cybernauts is observed in Eastern Europe. In Poland, this group increased from $40 \%$ to $47 \%$ in 2005 , and to $89 \%$ in 2008 . Throughout Europe, the percentage of young Internet users is growing with their age and this group is larger in Poland than in other EU member states (Tabak, 2015).

The strengths of this study lie in the large sample size and the use of new items enabling analyses of consequent parenting in relation to media use. The limitations include the reliance on the reports of children rather than objective measures of media use and parenting practices, possibly resulting in underreporting of using electronic media and overreporting of avoiding rules introduced by parents. Adolescents were asked only about introducing and following the rules for the use of electronic media, without information about the content of these rules. These issues should be taken into account in future studies.

To conclude, the results of the present survey lead to a clear conclusion: introducing and following rules for the use of electronic media protects the health of adolescents and is an element of good family relations. Health education programmes should be introduced for parents to show them the benefits of the authoritative parenting style and to teach them how to act consistently in matters regarding modern technology to prevent the adverse health effects of excessive use of electronic media by young people.

\section{Conflict of interest}

The authors do not report any financial or personal affiliations to persons or organisations that could negatively affect the content of or claim to have rights to this publication.

\section{Funding/Support and role of the sponsor}

This work was supported by the Institute of Mother and Child under grant number 510-20-18.

\section{References}

Alqahtani N, Furnell S, Atkinson S et al.: Internet risks for children: parents' perceptions and attitudes: an investigative study of the Saudi Context. In: 2017 Internet Technologies and Applications (ITA): 98-103.

Baumrind D: Current patterns of parental authority. Dev Psychol 1971; 4: 1-103.

Baumrind D: Differentiating between confrontive and coercive kinds of parental power-assertive disciplinary practices. Hum Dev 2012; 55: 35-51.

Baumrind D: The influence of parenting style on adolescent competence and substance use. J Early Adolesc 1991; 11: 56-95.

Bjelland M, Soenens B, Bere E et al.: Associations between parental rules, style of communication and children's screen time. BMC Public Health 2015; 15: 1002.
Boniel-Nissim M, Tabak I, Mazur J et al.: Supportive communication with parents moderates the negative effects of electronic media use on life satisfaction during adolescence. Int J Public Health 2015; 60: 189-198.

Brolin Låftman S, Modin B: School-performance indicators and subjective health complaints: are there gender differences? Sociol Health Illn 2012; 34: 608-625.

Brooks FM, Chester KL, Smeeton NC et al.: Video gaming in adolescence: factors associated with leisure time use. J Youth Stud 2016; 19: 36-54.

Cain N, Gradisar M: Electronic media use and sleep in school-aged children and adolescents: a review. Sleep Med 2010; 11: 735-742.

Cavallo F, Dalmasso P, Ottová-Jordan V et al.; Positive Health Focus Group: Trends in self-rated health in European and North-American adolescents from 2002 to 2010 in 32 countries. Eur J Public Health 2015; 25 Suppl 2: 13-15.

Christensen P: The health-promoting family: a conceptual framework for future research. Soc Sci Med 2004; 59: 377-387.

Currie C, Inchley J, Molcho M et al. (eds.): Health Behaviour in Schoolaged Children (HBSC) Study Protocol: Background, Methodology and Mandatory Items for the 2013/14 Survey. Child and Adolescent Health Research Unit (CAHRU), St. Andrews University, 2014.

Czapiński J, Panek T (eds.): Diagnoza społeczna 2015. Warunki i jakość życia Polaków. Rada Monitoringu Społecznego, Warszawa 2015. Available from: www.diagnoza.com.

Darling N: Parenting Style and Its Correlates. ERIC Digest. EDO-PS-99-3, Clearinghouse on Elementary and Early Childhood Education, University of Illinois, Illinois 1999.

De Decker E, De Craemer M, De Bourdeaudhuij I et al.; ToyBox-study group: Influencing factors of screen time in preschool children: an exploration of parents' perceptions through focus groups in six European countries. Obes Rev 2012; 13 Suppl 1: 75-84.

Duerager A, Livingstone S: How can parents support children's internet safety? EU Kids Online, London 2012.

Eurofound: Third European Quality of Life Survey - Quality of life in Europe: Families in the economic crisis. Publications Office of the European Union, Luxembourg 2014.

Eurostat: Being young in Europe today. Publications Office of the European Union, Luxembourg 2015. Available from: http://ec. europa.eu/eurostat.

Haddon L: Children's critical evaluation of parental mediation. Cyberpsychology (Brno) 2015; 9(1): article 2 .

Hofstra MB, Van Der Ende J, Verhulst FC: Adolescents' self-reported problems as predictors of psychopathology in adulthood: 10-year follow-up study. Br J Psychiatry 2001; 179: 203-209.

Inchley J, Currie D, Young T et al. (eds.): Growing up unequal: gender and socioeconomic differences in young people's health and wellbeing. Health Behaviour in School-aged Children (HBSC) study: international report from the 2013/2014 survey. Health Policy for Children and Adolescents, No. 7, WHO Regional Office for Europe, Copenhagen 2016.

Jago R, Davison KK, Thompson JL et al.: Parental sedentary restriction, maternal parenting style, and television viewing among 10to 11-year-olds. Pediatrics 2011; 128: e572-e578.

Kappos AD: The impact of electronic media on mental and somatic children's health. Int J Hyg Environ Health 2007; 210: 555-562.

Lenhart A: Teens, Smartphones \& Texting. Pew Research Center's Internet \& American Life Project, Washington 2012. Available from: https://www.fitsnews.com/wp-content/uploads/2012/03/ PIP_Teens_Smartphones_and_Texting.pdf.

Lee SJ: Parental restrictive mediation of children's internet use: effective for what and for whom? New Media Soc 2013; 15: 466-481.

Lei L, Wu Y: Adolescents' paternal attachment and Internet use. Cyberpsychol Behav 2007; 10: 633-639.

Livingstone S, Mascheroni G, Staksrud E: Developing a framework for researching children's online risks and opportunities in Europe. EU Kids Online, London 2015.

Mathers M, Canterford L, Olds T et al.: Electronic media use and adolescent health and well-being: cross-sectional community study. Acad Pediatr 2009; 9: 307-314. 
Mazur J: Dolegliwości subiektywne. In: Mazur J (ed.) Zdrowie i zachowania zdrowotne młodzieży szkolnej w Polsce na tle wybranych uwarunkowań socjodemograficznych. Wyniki badań HBSC 2014. Instytut Matki i Dziecka, Warszawa 2015: 85-92.

Newman K, Harrison L, Dashiff C et al.: Relationships between parenting styles and risk behaviors in adolescent health: an integrative literature review. Rev Lat Am Enfermagem 2008; 16: 142-150.

Ottova-Jordan V, Gobina I, Mazur J: Positive health. In: Inchley J, Currie D, Young T et al. (eds.): Growing up unequal: gender and socioeconomic differences in young people's health and well-being. Health Behaviour in School-aged Children (HBSC) study: international report from the 2013/2014 survey. Health Policy for Children and Adolescents, No. 7, WHO Regional Office for Europe, Copenhagen 2016.

Rideout V, Hamel E: The media family: electronic media in the lives of infants, toddlers, preschoolers and their parents. Kaiser Family Foundation, Menlo Park, CA 2006. Available from: www.kff.org.

Rideout VJ, Foehr UG, Roberts DF: GENERATION M². Media in the Lives of 8- to 18-Year-Olds. Kaiser Family Foundation, Menlo Park, CA 2010. Available from: www.kff.org.

Russ SA, Larson K, Franke TM et al.: Associations between media use and health in US children. Acad Pediatr 2009; 9: 300-306.

Schmidt ME, Vandewater EA: Media and attention, cognition, and school achievement. Future Child 2008; 18: 63-85.

Shin W: Parental socialization of children's Internet use: a qualitative approach. New Media Soc 2015; 17: 649-665.

Shin W, Kang H: Adolescents' privacy concerns and information disclosure online: the role of parents and the Internet. Comput Human Behav 2016; 54: 114-123.

Steinberg L, Blatt-Eisengart I, Cauffman E: Patterns of competence and adjustment among adolescents from authoritative, authoritarian, indulgent, and neglectful homes: a replication in a sample of serious juvenile offenders. J Res Adolesc 2006; 16: 47-58.

Steinberg L, Lamborn SD, Darling $\mathrm{N}$ et al.: Over-time changes in adjustment and competence among adolescents from authoritative, authoritarian, indulgent, and neglectful families. Child Dev 1994; 65: 754-770.
Strasburger VC, Jordan AB, Donnerstein E: Health effects of media on children and adolescents. Pediatrics 2010; 125: 756-767.

Strasburger VC, Wilson BJ, Jordan AB: Children, Adolescents, and the Media. $3^{\text {rd }}$ ed., SAGE Publications, Thousand Oaks, London, New Delhi 2014.

Śmiałowski T,Jałowiecki P, Woźniakowski T: Territorial diversification of technological exclusion in rural areas in Poland. Acta Sci Pol Oeconomia 2015; 14: 93-104.

Tabak I: Komunikacja z rodzicami za pomocą telefonu komórkowego. In: Mazur J (ed.): Zdrowie i zachowania zdrowotne młodzieży szkolnej w Polsce na tle wybranych uwarunkowań socjodemograficznych. Wyniki badań HBSC 2014. Instytut Matki i Dziecka, Warszawa 2015: 38-43.

Tabak I, Mazur J: Social support and family communication as factors protecting adolescents against multiple recurrent health complaints related to school stress. Dev Period Med 2016; 20: 27-39.

Van Lippevelde W, Bere E, Verloigne $\mathrm{M}$ et al.: The role of family-related factors in the effects of the UP4FUN school-based familyfocused intervention targeting screen time in 10- to 12-year-old children: the ENERGY project. BMC Public Health 2014; 14: 857.

Veldhuis L, van Grieken A, Renders CM et al.: Parenting style, the home environment, and screen time of 5-year-old children; the 'be active, eat right' study. PLoS One 2014; 9: e88486.

Viner RM, Ozer EM, Denny $S$ et al.: Adolescence and the social determinants of health. Lancet 2012; 379: 1641-1652.

Wille N, Bettge S, Ravens-Sieberer U; BELLA study group: Risk and protective factors for children's and adolescents' mental health: results of the BELLA study. Eur Child Adolesc Psychiatry 2008; 17 Suppl 1: 133-147.

Wolak J, Mitchell KJ, Finkelhor D: Does online harassment constitute bullying? An exploration of online harassment by known peers and online-only contacts. J Adolesc Health 2007; 41 (Suppl 1): S51-S58.

Wolak J, Mitchell KJ, Finkelhor D: Escaping or connecting? Characteristics of youth who form close online relationships. J Adolesc 2003; 26: 105-119. 